\title{
Why Do Russian Women Convert to Islam?
}

\author{
Izabela Kończak (iD) https://orcid.org/0000-0002-9938-8003 \\ Department of Middle East and North African Studies \\ University of Lodz \\ ikonczak@uni.lodz.pl
}

\begin{abstract}
The believers in Islam living in the Russian Federation are conventionally divided into two groups: autochthonous and immigrants. The first group includes Tatars and Bashkirs inhabiting Tatarstan, Bashkiria, the Volga Region, southern Ural, Siberia, and Moscow. The second Muslim zone in Russia is the northern Caucasus. Migrant Muslims are mostly incoming from neighboring states, former republics of the USSR. Their presence in Russia is based on economic grounds. Along with the abovementioned ethnic Russian Muslims, there are also Russians of Slavic origin, who have converted to Islam for various reasons.

The article discusses the motivations of Russian (Slavic) females converting to Islam. The analysis is based on the quantitative and qualitative content of messages posted on two web forums: Evimturkiye.com, in a thread entitled Change of confession. I adopted Islam; and forumok.ru, in the thread $A$ woman in Islam. The author makes an attempt to answer the question of why Russian women convert to Islam.
\end{abstract}

Keywords: Russian women, conversions, Islam, motivations

Slowa kluczowe: Rosjanki, konwersje, islam, motywacje

One of the more important elements of perestroika and of Russia's developmental directions at the turn of 1980s and 1990s was the freedom of religious worship. Establishment of freedom of religion can be seen as one of the elements of liberalization of the Soviet regime, and after the fall of the USSR, as an element of democratization. The symbolic date of religious rebirth in the territory of today's Russia is 1988, when the anniversary of the baptism of Rus was officially celebrated on the state level. The events that followed clearly showed how the relation between state and religion was changing. ${ }^{1}$ As an effect, the society, forcibly atheized for more than 60 years

1 A. Malashenko, Islam "legalizovannyi” $i$ vozrazhdënnyi, [in:] A. Malashenko, S. Filatov (eds.), Dvadcat'let religioznoy svobody v Rossii, Moskva 2009, p. 240. 
and taught to keep their religious practices at home, could move directly to the stage of confessional pluralism. It is also noteworthy that the constitution of the Russian Federation specifies four religions - Orthodoxy, Islam, Buddhism, and Judaism - as the traditional ones; other religions can exist, but they are not state subsidized. ${ }^{2}$

The worshippers of Islam living in the Russian Federation are generally divided into two groups: indigenous and migrant persons. The first group includes Tatars and Bashkirs inhabiting Tatarstan, Bashkiria, the Volga Region, southern Ural, Siberia, and Moscow. Tatars, with a headcount of 5.5 million, are more numerous than Bashkirs, at approximately 1.6 million. ${ }^{3}$ The other Muslim zone in Russia is the Northern Caucasus, where the total number of worshippers of Islam is assessed at 7 million people. The number of indigenous Muslims in Russia is approximately 14 million, more than 10\% of the total population. Migrant Muslims are mostly incoming from neighboring countries - the former Soviet Republics. Their presence in Russia has economic grounds: they are leaving their homelands in search of better life for themselves and their families. The immigrant communities are also fed by people from Middle East and Africa, mostly from states previously supported by the USSR. ${ }^{4}$ The overwhelming majority of Russian Muslims are Sunni, representatives of the most liberal, Hanafi school of law. ${ }^{5}$ Some Muslims in the Northern Caucasus are followers of the Shafi'i school, but the region is also known for the popularity of Sufi traditions, especially of the Naqshbandi and Qadiri orders. ${ }^{6}$

Along with the abovementioned ethnic Russian Muslims, there are also Russians of Slavic origin who have converted to Islam for various reasons. In the opinion of Elena Stepanova, in the early twentieth century Orthodoxy was practically the only denomination in Russia, the one that every Slavic Russian should identify with. ${ }^{7}$ Moreover, according to statistical surveys, more than $80 \%$ of Slavic Russians still describe themselves as Orthodox. ${ }^{8}$ However, more and more often they are leaving their religion of birth for a religion of their conscious choice. The theme of islamization of Russians - traditionally seen as the Christians of the Eastern rite - has been

${ }^{2}$ Ibidem.

${ }^{3}$ Naselenie Rossii. Statistika, fakty, kommentarii, prognozy, http://www.rf-agency.ru/acn/stat_ru.htm [access: 10.09.2017].

${ }^{4}$ B. Cichocki, M. Marszewski, K. Strachota, Islam w europejskiej części WNP, [in:] Islam na obszarze postradzieckim, "Prace OSW" 2003, no. 7, January, Ośrodek Studiów Wschodnich, Warszawa, pp. 68-69.

${ }^{5}$ Y. Kobishchanov, Musul'mane Rossii, korennye rossiyskiye musul'mane i russkiye musul'mane, http://www.tatar-history.narod.ru/musulmane-rossii.htm [access: 10.09.2017].

${ }^{6}$ M. Łabenda, Muzutmanie w Rosji i europejskiej części bytego ZSRR, [in:] A. Parzymies (ed.), Muzulmanie w Europie, Warszawa 2005, p. 252.

${ }^{7}$ E.A. Stepanova, Religioznaya situatsiya $v$ Rossii $i$ osnowy mezhkonfessional'nykh vzaimootnosheniy, "Nauchnyy ezhegodnik Instituta Filosofii i Prava ural'skogo otdeleniya Rossiyskoy Akademii Nauk" 2003, no. 4, p. 358.

${ }^{8}$ V. Fedorov, Rossiyskaya identichnost'i vyzovy vremeni. Tezisy $k$ vystupleniyu v Potsdame 5 iyunya 2013 g., https:/wciom.ru/fileadmin/file/reports_conferences/2013/2013-06-05-rossiya-ES.pdf [access: 12.02.2018]. 
drawing the attention of writers, ${ }^{9}$ becoming a subject of research in the field of political sciences ${ }^{10}$ and sociology, for the past several years, i.e. since the phenomenon was recognized and identified as unique. ${ }^{11}$ It is difficult to ascertain clearly how many neophytes there are in Russia, as the public census does not ask respondents to declare a religion. The available estimates are highly contradictory. Figures shown by different mass media vary from a few hundred to a few hundred thousand people. A leader of the erstwhile National Organization of Russian Muslims (NORM), Vadim Sydorov, who took the Arabic name of Harun ar-Rusi, claims at the moment there are 150,000 newly converted Muslims. ${ }^{12}$

The purpose of this article is to respond to the titular question by investigating what female Russian internet users publish on online forums about their own conversion, or that of other women around them. However, one can indicate various psychosocial conditions which favor such conversion. It is usually useful to try to answer the question: can the conversion of such persons be seen as a special type of religious growth, preceded by conscious and emotionally mature analysis and inner struggle leading to verification of earlier religious attitudes? Did the search for a new religious path constitute an independent choice of these women? Or is it possible the reasons are different: was the adoption of Islam a strictly formal change, made as an effect of situational factors, such as family conflicts, and was the decision made under the influence of third persons? The subject of the analysis are the contents of the posts of converted females published on selected Russian-language internet forums, where they show the motivation for the change of their religion.

\section{The number of Russian Muslims and conversion motivations}

On one hand, public discourse is shaped by alarmist opinions, such as those expressed by Yuri Golubchikov and Ruben Mnatsakanyan, the authors of Islamization of Russia. The dreadful scenarios of the future, who claim that islamization of Russians (on year-to-year basis) has spanned 5\% of society, and that $70 \%$ of persons visiting mosques in Russian cities are Slavic Muslims. ${ }^{13}$ Under critical scrutiny, the

9 See for example Pochemu nekotorye russke stanovyatsya musul'manami, http://www.newsru.com/ $\mathrm{arch} / \mathrm{russia} / 15 \mathrm{sep} 2004 /$ islamm.html [access: 10.09.2017].

10 See for example A. Verkhovskiy, Publichnye otnosheniya pravoslavnykh $i$ musul'manskikh organizacij na federal'nom urovne, [in:] A. Malashenko (ed.), Islam v Rossii. Vzglyad iz regionov, Moskva 2007, pp. 123-152; S. Filatov, Mnogotsvetiye volshebnogo sada rossiyskoy dukhovnosti: dvadtsat' let vozrastaniya rieligioznogo mnogoobraziya postsowetskoy Rossii, [in:] A. Malashenko, S. Filatov (eds.), Dvadcat'let religioznoy svobody v Rossii, op. cit., pp. 8-40.

11 See for example Y. Gavrilov, A. Shevchenko, Russkie musul'mane $w$ pole rossiyskoy identichnosti, [in:] M. Gorshkov (ed.), Rossiya reformiruyushchayasya, Wyp. 7, Institut sociologii RAN, Moskva 2008, pp. 289-303.

${ }_{12}$ Kazhduyu pyatnitsu v Peterburge kak minimum troe russkikh prinimayut islam, http://www.gazeta.spb.ru/59023-0/ [access: 10.09.2017].

13 Y.N. Golubchikov, R.A. Mnatsakanyan, Islamizatsiya Rossii. Trevozhnye stsenarii budushchego, Moskva 2005, p. 388. 
first figure especially seems highly questionable - as the book was published several years ago, Islam should be by now the dominant religion of the Russian Federation. However, the authors correctly identified the fear of Islam as expressed by Russian public opinion. On the other hand, the St. Petersburg-based orientalists Boris Podoprigora and Yefim Rezvan assess that the change of denomination among Russians and conversion to Islam is not a mass phenomenon. It might apply to only a few dozen people per year. In their opinion Islam is preferred by the Russian inhabitants of Muslim republics over the indigenous Russian regions. ${ }^{14}$ Representatives of the Russian Orthodox Church express a similar view. Orientalist Roman Silantev, an academic and formal official of the Orthodox Church, estimated the number of new Muslims at seven thousand people. ${ }^{15}$ The popular Russian website www.islam.ru, devoted to Slavic Muslims, has more than 2,500 registered users.

Regardless of the problems with determining the size of the discussed group, the very phenomenon of conversion of Russians to Islam seems troubling. The public imagination is strongly influenced by tangible facts which do not require any clarification or interpretation - for example, a second mosque was opened in St. Petersburg in 2008, because the existing one, designed for 7,000 worshipers, could not hold all the people willing to bow in front of the one and only God. ${ }^{16}$ Islamic Studies scholar Alexei Malashenko claims that the tendency of proliferation of Islam among the Slavic inhabitants of Russia will only become stronger and cannot be avoided. ${ }^{17}$ Curiously, the conversion of ethnic Russians to Islam is not a new phenomenon. Conversions were observed as early as in the nineteenth century, which were then associated with the Caucasian War. At the time, Russian soldiers who became prisoners of Imam Shamil's forces decided to adopt Islam for various reasons. Quite often, according to the pre-Muslim Caucasian tradition, new Muslims were taken into highlander Chechen families in lieu of men who fell in battle, acting as adopted sons. Regardless of the customary requirements, such a step did not always mean their unconditional acceptance by the local communities. The highlanders neither trusted nor believed the newcomers - at least not immediately. Their loyalty had to be continuously verified, by, for example, a series of difficult tasks. With time, trust grew, and some Russians became members of Chechen families through blood ties. Conversions to Islam also happened during the Russian intervention in Afghanistan (1979-1989), and the First (1994-1996) and Second (1999-2000) Chechen Wars. ${ }^{18}$

Today it is mostly young persons, not older than 30, primarily from student circles, who convert to Islam. ${ }^{19}$ This is not unusual, as Edwin D. Starbuck had already

${ }^{14}$ Kazhduyu pyatnitsu v Peterburge kak minimum troe russkikh prinimayut islam..., op. cit.

${ }_{15}$ V. Ivanov, Radikal'nyy islam sredi russkikh Powolzhya i ego posledstviya, http://www.riss.ru/ analitika/2573-rasprostranenie-radikalnykh-techenij-islama-v-srede-russkogo-naseleniya-povolzhyaiego-posledstviya\#.VANdK3RmMsc [access: 18.09.2017].

${ }^{16}$ Skoro v Peterburge poyavitsya vtoraya miechet', http://www.fontanka.ru/2007/05/03/083/ [access: 23.09.2017].

${ }^{17}$ A. Malashenko, Naselenie prodolzhat vovlekat'v islam, http://www.carnegie.ru/ publications/?fa $=45245$ [access: 23.09 .2017 ].

${ }^{18}$ Kazhduyu pyatnitsu v Peterburge kak minimum troe russkikh prinimayut islam..., op. cit.

${ }^{19}$ Ibidem. 
noticed the ties between religious conversion and adolescent growth. ${ }^{20}$ The motives for the adoption of the new faith are varied. According to Golubchikov and Mnatsakanyan the reason for conversion to Islam was the economic situation of the country and, predominantly, the wild "market-oriented democracy," difficult for young people to bear. Islam offers them a feeling of attachment to tradition and righteous organization of life in concordance with God. Additionally, the Muslim community provides spiritual support not only within the mosque. Allegedly, Russians cannot find these values in the commercialized Orthodox Church, where "even participation in a service without money became embarrassing." ${ }^{21}$ However, it seems the issue is more complex. Russia is a multinational and multi-ethnic country, and the inherent pluralism seems to have a significant impact, changing the spectrum of experiences of an individual. The surrounding diversity may lead to confrontation with numerous different concepts of life. The availability of publications and opportunities to exchange views with people of other denominations helps to relativize the older values. In the opinion of Peter L. Berger, the contemporary world is not taken for granted in a secure, obvious, and unambiguous manner. ${ }^{22}$ As far as convictions are concerned, a human being is able to rely only on their own subjective feelings and experiences, and therefore people more and more often search and experiment in the sphere of inner life. ${ }^{23}$

Converts to Russian Islam clearly do not form a monolithic group. They can be divided into several characteristic types - mostly due to reasons which push the individuals to adopt Islam. When reviewing the existing classifications, ${ }^{24}$ the context of the article suggests adopting that offered by Anatoliy Artyomov, an Orthodox publicist, who divides converts into two groups: people who have turned to Islam as an effect of spiritual explorations, and those who have converted to Islam for other,

${ }^{20}$ E.D. Starbuck, The Psychology of Religion: An Empirical Study of the Growth of Religious Consciousness, New York 1911, pp. 28-30, https://archive.org/details/psychologyofreli00star [access: 12.02.2018]. This thesis is confirmed by research carried out in Russia by Aleksandr Golov, see: A. Golov, Obrashchenye k religii i ego znachenye v segodnashney zhyzni rossiyan, "Monitoring obshchestvennogo mnenya" 1998, no. 1 (33), p. 40.

${ }_{21}$ Y.N. Golubchikov, R.A. Mnatsakanyan, op. cit., p. 388.

22 P.L. Berger, T. Luckmann, The Social Construction of Reality. A Treatise in the Sociology of Knowledge, London 1991, p. 70, http://perflensburg.se/Berger\%20social-construction-of-reality.pdf [access: 12.02.2018].

${ }^{23}$ M. Libiszowska-Żółtkowska, Konwertyci nowych ruchów religijnych, Lublin 2003, p. 301.

${ }^{24}$ An interesting classification was proposed by the analyst of the Russian Institute of Strategic Studies, Vasiliy Ivanov, who divides the discussed group into four categories: ideologists, converts guided by family reasons, opportunists, and soldiers forcibly converted to Islam, see: V. Ivanov, op. cit. The same classification is given by Rais Suleymanov, Russkye musulmane: klassifikatsya grupp, problema radikalizma, otnoshenye k nim v Rossii, "Musulmanskiy mir" 2015, no. 4, pp. 12-13. Classification used by Andrey Ignatev assumes four separate groups among the new Russian Muslims: (1) persons who marry a worshipper of Islam, (2) persons attracted to Islam by the mystique of the religion, so-called Searchers for God, (3) persons consciously adopting Islam, (4) persons who are attracted to Islam by radical groups of all kinds. See: A. Ignatev, Pochemu russkie prinimayut islam, http://www.schwarz-front.ru/ islam3 00509.htm [access: 20.10.2014]. 
predominantly family-related reasons..$^{25}$ The latter group, possibly more numerous, consists first of all of women marrying Muslims. Marriage to a Muslim - an Arab, a Turk, or a man from the Caucasus - is becoming more and more popular among young Russian women. ${ }^{26}$ It seems that in comparison, the appearance of Russian men is not male enough, "they appear pitiful with their tattoos, earrings and a beer in hand, while Chechens are mature since they were kids." ${ }^{27}$ Muslim men, in the opinion of their Russian wives, are perfect candidates for a husband, as they do not drink alcohol, and bring all the money they earn home, thus becoming the object of desire of the Slavic women of Russia. ${ }^{28}$ Women believe "Muslim nations, their tradition and culture are still based on what we had lost long ago - respect for women. Muslim men are not cowards and alcoholics." ${ }^{29}$ Statistical data confirm most converts throughout the world are women: $66 \%$ of all new Muslims are female, and only $34 \%$ are male, ${ }^{30}$ suggesting that women adopt Islam twice as often as men. The same tendency is observed in the Russian Federation. According to data collected in the Moscow-based mosque on Poklonnaya Gora, the number of Russian female Muslims has tripled within the last two years. ${ }^{31}$ The rising tendency is also confirmed by Dzhamaliddin Makhmutov, vice-president of Al-Fath, a Muslim organization in St. Petersburg, who says: "If one would judge by our madrasa only, the trend is visible. The majority are women converting to Islam to maintain harmony in the family." 32

\section{Research and analysis of the results}

In order to investigate what Russian women think about their own conversion to Islam, or that of other women from their environment, the author of this paper analyzed the content of posts on two Internet forums: Evimturkiye.com, on a thread

25 A. Artyomov, Mnogo li w Rossii „,russkikh musul'man”?, “Tserkovnyy viestnik” 2003, no. 17 (270), sentyabr', http://tserkov.info/numbers/churchsociety/?ID=590\&forprint [access: 10.10.2017].

${ }^{26}$ See for example T.L. Bokova, Osnovnye tendentsii razvitiya mezhnatsionalnoy semii v rossiyskom obshchestve, "Izvestya Tomskogo Politekhnicheskogo Univeristeta" 2007, no. 7, vol. 311, p. 105; S. Sirazhudinova, Neofity v strukture radikalnogo islama, "Informatsyonnye voyny" 2015, no. 4 (36), p. 97.

27 V. Ivanov, op. cit.

${ }^{28}$ I. Sergeyev, Russkie musul'manki. Pochemu moskovskiye devushki prinimayut islam?, http:// www.centrasia.ru/newsA.php?st=1071330060 [access: 20.10.2014].

${ }^{29}$ Istorii tekh, kto prinyal Islam. Mashha Allakh!, http://al-ihlas.narod.ru/story.html [access: 10.10.2017]. At this point, it is worth mentioning the case of Varvara Karaulova, who met - through one of the social networking sites - Ayrat Samatov from Kazan, who was a member of the so-called Islamic State. Under the influence of their correspondence and feelings, the girl decided to accept Islam. She even suggested that Samatov should marry her and that she would go to Syria. See: S.P. Doronin, K.V. Fyodorov, Fenomen zhenskogo terrorizma i problema ego interpretatsii v obshchestve, "Kazanskiy pedagogicheskiy zhurnal” 2016, no. 3, p. 175.

${ }^{30}$ Pochemu zhenshhiny prinimayut islam, http://islam-today.ru/zhenshhina_v_islame/pochemu_ zhenshhiny_prinimayut_islam/ [access: 12.02.2018].

${ }^{31}$ Russkikh musul'manok stanovitsya vse bolshe..., http://islam-info.ru/zhenskii-razdel/1169russkix-musulmanok-stanovitsya-vse-bolshe.html [access: 10.10.2017].

${ }^{32}$ Kazhduyu pyatnitsu v Peterburge kak minimum troe russkikh prinimayut islam..., op. cit. 
entitled Change of confession. I adopted Islam, and on forumok.ru, on the thread Woman in Islam. In total, the contents of 1,484 posts published in these threads, written by 172 persons, were analyzed. After preliminary selection, posts not written by women ( 2 persons) or posts limited to questions or disputes with other persons without presentation of one's own views (52 persons) were rejected. 118 women remained in the study group. The group included 16 non-Slavic women: Tatars, Bashkirs, and those from the Caucasus. In these cases, one can only assume that for all of them, Islam is their religion of birth. ${ }^{33}$ The remaining group of 102 Slavic females showed three distinct approaches: 44 of them adopted Islam (which allows them - seemingly - to compare the published opinions with actual experiences, and not to speak only on the basis of imagination or expectations), 23 women declared intentions of conversion in the future, while 35 claimed that they were reluctant to change their religion. What is noteworthy, all the women in the last category are wives of Muslims. However, there are no grounds to associate experience of mixed marriage with reservations towards conversion to Islam. Such opinions are not present in the examined threads. Women simply claim that co-existence of different religions within a relationship is totally feasible. Sachagumus says: "My husband told me: if you adopt Islam, I shall be happy; if not - you are more important for me than religion. And this is how we live. Right now, I don't even remove the cross I wear on my neck and I am closer to my religion." ${ }^{34}$ Maintenance of the denominational status quo in a relationship can, however, produce problems, and the forum contributors are aware of that. Podsnejnik writes: "At the moment it is all peace and quiet, but earlier on, we had these regular conversations. 'You will not have to fulfill all the duties or wear a hijab, you won't even have to pray. Adopt Islam formally and live how you want to live." ${ }^{35}$ Not all women are as stern in their resolve to refuse to change religions; however, it must be admitted the hesitant wives, those who consider such an option, are definitely a minority. Only two out of 35 women declared they could sacrifice and convert to Islam for the sake of their family. Sohal writes bluntly: "I am not going to change religion myself, but it is a major issue for our family." ${ }^{36}$ Lunara, however, is less resolute, as she admits: "I might adopt Islam, but I do not want to stress my parents out. I have no idea what the procedures are. I have been in the Orthodox church a few times, but I returned so shocked, I've never gone there again." ${ }^{37}$

The forum posts were used to excerpt the reasons why Russian females have converted or are planning to convert to Islam. In most cases women are adopting or intending to adopt Islam for family reasons. This is confirmed by the contents of 33 entries where women claim they converted because of marriage with a Muslim man, and in 16 subsequent posts women declare those changes are due to

${ }^{33}$ Cf. very interesting research on the religious identity of the Tatars. G.A. Sabirova, Formirovanye religioznoy identichnosti $v$ megapolise (na primere zhenshchin-tatarok, obuchaushchikhsya na religioznykh kursakh v Moskve, Moskva 2006.

${ }^{34} \mathrm{http}: / /$ evimturkiye.com/forum/93-2794-6 [access: 30.09.2017].

${ }^{35} \mathrm{http}: / /$ evimturkiye.com/forum/93-2794-4 [access: 30.09.2017].

${ }^{36} \mathrm{http}: / /$ forum.forumok.ru/index.php?showtopic $=9288 \& \mathrm{st}=280$ [access: 02.10 .2017 ].

${ }^{37} \mathrm{http}: / /$ forum.forumok.ru/index.php?showtopic $=9288 \& \mathrm{st}=400$ [access: 02.10 .2017 ]. 
a relationship with a follower of Islam. Tatiana declares openly: "I got married and I adopted Islam." ${ }^{38}$ Natalia1221 writes: "My boyfriend is a Muslim and I am ready to adopt Islam for him. At the moment I am learning everything. I am not an eager Christian. The wedding is planned for autumn. I want him to be happy with me. [...] He does not insist on my conversion. ${ }^{39}$ It is noteworthy that this group of converts (and intended converts) can be subdivided into several groups. Among the women, 36 adopted or will adopt Islam because the man has put some emphasis on the fact. A good example is Sandra, who writes: "I adopted Islam back in my homeland. Also, because he wanted that and I loved him a lot. Of course he did not say it out loud, because you cannot force anybody to become Muslim, but the meaning was clear - if you do not turn to Islam, we will not be together. Something tempted me to agree. The entire procedure was performed on the Internet, via Skype. As an obedient girl in love I started to read everything (about Islam) and observe (the rules). ${ }^{{ }^{40}}$ In turn, Olivka25 recalls her conversion in the following manner: "I converted to Islam. [...] How did it happen? I wanted to become a Muslim, but not so fast. I was preparing myself for this moment for three years. And for three years I still hoped it would not happen. And right after the marriage, my husband took me there, without even warning me." ${ }^{41}$ Fatima writes: "I love my husband a lot [...], he is a Muslim, born and bred. I tried everything and I finally understood: either I need to convert to Islam or get a divorce." ${ }^{42}$ Five women took the Shahada, because another family member, not the husband, insisted on their conversion. A poster nicknamed Tolokno1985 describes her situation: "He said - I am planning to marry you, BUT my mother, grandmother and aunt would like you to become Muslim very much." ${ }^{43}$ Most often the person applying pressure was the mother of the husband, as in the case described by Rusdiamond: "How did I decide to convert to Islam? My mother in law - a very religious person - persuaded me to do so. She wanted me to go to paradise." ${ }^{44}$ Eight other women converted or will convert to Islam with other justifications, albeit still described as "family reasons." Most often the goal is to avoid conflicts. El'machka comments: "In time I will convert to Islam, either before the betrothal or the wedding, because I am convinced there should be only one religion in my family." 45 OksanNika presents it thus: "If you have a choice between the beloved man and family harmony on one hand, and remaining Christian on the other hand, I choose peace in the family." ${ }^{46}$ Katrysya writes: "As I understand tolerance, I should not judge my neighbor, but it does not mean that within my own family there should be anarchy

\footnotetext{
$38 \mathrm{http}$ //forum.forumok.ru/index.php?showtopic=9288\&st=240 [access: 02.10.2017].

$39 \mathrm{http}$ //forum.forumok.ru/index.php?showtopic=9288\&st=1060 [access: 02.10 .2017 ].

$40 \mathrm{http}: / /$ evimturkiye.com/forum/93-2794-3 [access: 30.09.2017].

41 http://evimturkiye.com/forum/93-2794-5 [access: 30.09.2017].

${ }^{42} \mathrm{http}$ ://forum.forumok.ru/index.php?showtopic=9288\&st=420 [access: 02.10.2017].

$43 \mathrm{http}: / /$ evimturkiye.com/forum/93-2794-12 [access: 30.09.2017].

${ }^{44} \mathrm{http}$ //evimturkiye.com/forum/93-2794-6 [access: 30.09.2017].

$45 \mathrm{http}: / /$ evimturkiye.com/forum/93-2794-6 [access: 30.09.2017].

46 http://evimturkiye.com/forum/93-2794-11 [access: 30.09.2017].
} 
and everyone should have their own god." ${ }^{47}$ In the above cases one might risk the opinion that women remain an object, not a subject of change, and passively submit to the will of the partner, close persons, or undefined "external conditions." The phenomenon does not necessarily refer to pressure or forced conversion. However, it matches the symptoms of change described by George A. Coe - not performed by the converts themselves, but by other participants, where change is rendered upon converts, without inspiration from their side. ${ }^{48}$

Sociologists emphasize it is necessary to distinguish conversion from a nominal change, resulting from, e.g., family matters or other external conditions ${ }^{49}$ Based on the quoted entries, one can assume the conversion to Islam is for these women a purely formal procedure, without any serious philosophical motivation (at least in most cases). Selected entries in the analyzed threads seem to confirm such an assumption. For example, Swallowfox writes: "I am a Muslim too. My husband is a believer, who observes all the rules and prays every day, but I somehow cannot make myself do it..." ${ }^{50}$ In turn, Kalifa, attempting to somehow justify the superficiality of her faith, observes: "I am a Muslim as well... but my iman is poor... I do not understand everything... I do not understand." ${ }^{51}$ Nevertheless, still many converts adapt to their husbands' environment, and in time even become practicing Muslims, who observe the rules of Sharia. Boris Podoprigora notices that despite all this, women from this group basically see the change of religion as an addition to the change of last name. ${ }^{52}$

A different group comprises 18 women who are forum users claiming they converted or will convert to Islam in a conscious manner - not under the influence of relatives, not to stop or avoid conflicts, but as a result of personal reflections and explorations. Asya Khanym writes: "I converted to Islam almost 5 years ago, without any pressure or obligation, out of my choice [...] I started university studies at the Faculty of Oriental Studies, with major in Turkish studies. My first essay was about Muslim mysticism - Sufism - and this is how it all started... reading literature, long discussions with my Muslim sisters... and suddenly I realized the balance is tipping more and more towards Islam." ${ }^{33}$ Meanwhile, Astrit claims: "I have a husband, we will have a Muslim wedding, the official wedding will be on 3 December. I converted to Islam on 13 July 1998, I remember it was Friday and the 13th day of the month. I converted to Islam before I met my husband. The most important thing is to have faith in your soul... I know a lot about Islam and I am a believer, but my entire family are Christians, I was raised to respect other people, and especially faith." ${ }^{54}$ As many as 12 of the women declare their conversion has been, or shall be, conscious,

\footnotetext{
${ }^{47} \mathrm{http}$ ://forum.forumok.ru/index.php?showtopic=9288\&st=580 [access: 02.10.2017].

${ }^{48}$ G.A. Coe, The Psychology of Religion, Chicago 1917, p. 153, https://www.questia.com/read/ 24458028/the-psychology-of-religion [access: 12.02.2018].

${ }^{49}$ E. Hałas, Konwersja - perspektywa socjologiczna, Lublin 1992, p. 52.

${ }^{50} \mathrm{http}: / /$ forum.forumok.ru/index.php?showtopic $=9288 \& \mathrm{st}=960$ [access: 02.10 .2017$]$.

${ }^{51} \mathrm{http} / / /$ evimturkiye.com/forum/93-2794-5 [access: 30.09.2017].

${ }_{52}$ Kazhduyu pyatnitsu $v$ Peterburge kak minimum troe russkikh prinimayut islam..., op. cit.

${ }^{53} \mathrm{http}$ ://forum.forumok.ru/index.php?showtopic $=9288 \&$ st $=0$ [access: 02.10 .2017 ].

${ }^{54} \mathrm{http}: / /$ forum.forumok.ru/index.php?showtopic $=9288 \& \mathrm{st}=360$ [access: 02.10 .2017 ].
} 
even emphasizing that the relationship with a Muslim man was/is not a major reason behind their decision. Astra77 comments: "I consciously decided to convert to Islam. I listened to Quran translations, I read articles on the Web, I listened to YouTube lectures. Of course, I do not know everything, one might say I am a freshman. When I was thinking about it, I asked myself a question: have I done it for myself? If I ever part ways with my Turk, how will I be able to continue living with it? Therefore I did not hurry, I listened to the voice in my heart." ${ }^{55}$ At the same time Green Eyes believes "modern Christianity is not for [her], as it involves worship of portraits - icons, and refuses to address certain contradictions. Especially prayers starting with words 'Jesus, our Lord...' when Jesus himself said: 'Let him be accursed anyone, who next to my words, shall add that I am the son of God.' I read the necessary literature, The Quran. I learn from my husband, his mother and sister." ${ }^{56}$ Certainly, at least in some cases, the motivation for conversion is more complex and cannot be reduced to a search for a new spiritual way. It is possible to look for unintentional but still tangible influences of the surroundings and the persons closest to them. The depth and zeal of such spiritual explorations do not always match the declarations of conscious choice, as forum users emphasize what is important: a significant motivator to learn about the religion and to acknowledge their related expectations was still the Muslim man they had met. This is how Lizaveta93 puts it: "I converted to Islam not because of a man, but because my heart told me so. It is likely that contacts with my current husband, at that time my boyfriend, who is a Turkman, were a stimulus to know and become interested in religion." 57

Some women point to "deficiencies" or "imperfections" of their previous religion as the motivation for the change. Such a negative impulse in the search for a more suitable denomination is declared by four forum users. They define themselves as believers, but are deterred from the Orthodox religion by, for example, the unintelligible dogma of the Holy Trinity. Lale writes:

When I was reading The Quran I started to understand how many Muslim rules and standards of behavior are closer to the reality of contemporary life than the Christian ones. For instance, the Christian idea of forgiveness and the commandment to turn the other cheek if someone hits you! You will not get far in life with that, because life is a struggle. In Islam there is one God, and in Christianity I have always been puzzled by the presence of God, His Son, and the Holy Spirit. $^{58}$

In turn, Khadija1988 describes the reasons for her conversion as follows: "I read a lot of books on various religions, I always believed in God, but I did not accept icons and the concept of the Trinity. Along with Islam, I also studied Judaism and Buddhism." ${ }^{59}$ Habiba was a similar explorer, as she writes: "Issues of faith were always central for me. When I was Orthodox, I prayed to the icons, and then I thought:

\footnotetext{
$55 \mathrm{http}: / /$ evimturkiye.com/forum/93-2794-6 [access: 30.09.2017].

${ }^{56} \mathrm{http} / / /$ evimturkiye.com/forum/93-2794-7 [access: 30.09.2017].

${ }^{57} \mathrm{http} / / /$ evimturkiye.com/forum/93-2794-10 [access: 30.09.2017].

${ }^{58} \mathrm{http}: / /$ evimturkiye.com/forum/93-2794-2 [access: 30.09.2017].

${ }^{59} \mathrm{http}: / /$ evimturkiye.com/forum/93-2794-8 [access: 30.09.2017].
} 
why do we pray to images? Then, when I was a Protestant, I prayed to Christ every day [...] And in Islam it is all simple. My mind is satisfied, my heart is at peace, and this is the most important thing. With me it was different than with Natalya, who thought she changed her God. I simply stopped worshipping human beings, because I have been praying to God forever." ${ }^{\circ 0}$ For two other women, Islam offers a kind of rest or tranquility. Amina B writes this religion is closer to her and makes her feel calmer, ${ }^{61}$ while Ollune observes that in the Orthodox Church she is always uneasy, but in the mosque she is calm and satisfied. ${ }^{62}$

\section{Conclusions}

Assessment of the quoted sources and the comments from scholars and researchers shows that family matters are the most common motivation for Russian females converting to Islam. At the same time, how the females subjectively perceive the family is actually not all that significant, while family life-values are important to them or sufficient to inspire them to take far-reaching steps - including change of religion. The examined group included both women who converted to Islam because of their concern for family harmony, peace, and safety in a circle of close people, and women who saw marriage to a Muslim - and in consequence the change of religion - as an achievement of a satisfactory goal in the consumption-oriented world, where everything can have its price, and each step situates them in a community, social, or even virtual hierarchy. Marriage with a Muslim appears to be more attractive for women than marriage with a non-Muslim - even more so when comparing the image of the "typical" Slavic Russian man, which girls and young women nurture, with a similar, strictly theoretical "creation," an idealized follower of Islam. ${ }^{63}$ The fact that on occasion in a mixed relationship the religion also changes ("as part of the package") is insignificant - especially when religion is seen as something obvious, formal, and not requiring any deeper attention, just like adopting the husband's last name. Interestingly, even those who claim to have converted to Islam as an effect of long reflection, not resulting from personal or family situations, imply that their search for a new way was spurred by the presence of a Muslim man - friend, boyfriend, or fiancé - in their immediate environment, even if the love interest has never been fulfilled. In this case one can also argue about the similarity of motivations, even if not strictly familyrelated, but surely of a similar nature, in a sense.

The other important observation refers to the superficiality of opinions and judgments. The participating women often totally unreflectively idealize their beloved man or the intentions of the closest family pushing them to conversion, or even the practices and rules of the newly adopted religion. This is understandable, as persons

${ }^{60} \mathrm{http}: / /$ forum.forumok.ru/index.php? showtopic $=9288 \& \mathrm{st}=40$ [access: 02.10 .2017 ]

${ }^{61} \mathrm{http}: / /$ evimturkiye.com/forum/93-2794-12 [access: 30.09.2017].

${ }^{62}$ Ibidem.

${ }^{63}$ I. Kończak, Motywacje Rosjanek poszukujacych muzutmańskiego męża. Próba rekonstrukcji postaw, "Historia i Polityka" 2017, no. 19 (26), pp. 79-95. 
offering their testimonies seek to rationalize their own decisions or are ultimately living in a state of neophyte zeal. Especially when reading the threads displaying a clear fascination with the unknown, one should not expect any critical perspectives on the idealized partner or their religion. However, it is noteworthy that even in cases of women declaring themselves as conscious converts, close scrutiny of their posts sometimes calls into question the quality of their explorations, or the seriousness or reliability of the sources on which they base their opinions - and which include everything from free conversations with the new family, or with anonymous forum users, to Web articles and videos in YouTube-style services.

\section{References}

Artyomov A., Mnogo li w Rossii „,russkikh musul'man”?, “Tserkovnyyviestnik” 2003, no. 17 (270), sentyabr', http://tserkov.info/numbers/churchsociety/?ID=590\&forprint.

Berger P.L., Luckmann T., The Social Construction of Reality. A Treatise in the Sociology of Knowledge, London 1991, http://perflensburg.se/Berger\%20social-construction-of-reality.pdf [access: 12.02 .2018$]$.

Bokova T.L., Osnovnye tendentsii razvitiya mezhnatsionalnoy semii v rossiyskom obshchestve, "Izvestya Tomskogo Politekhnicheskogo Univeristeta” 2007, vol. 311, no. 7, pp. 103-106.

Cichocki B., Marszewski M., Strachota K., Islam w europejskiej części WNP, [in:] Islam na obszarze postradzieckim, "Prace OSW" 2003, no. 7, January, Ośrodek Studiów Wschodnich, Warszawa, pp. 68-69.

Coe G.A., The Psychology of Religion, Chicago 1917, https://www.questia.com/read/24458028/ the-psychology-of-religion [access: 12.02.2018].

Doronin S.P., Fyodorov K.V., Fenomen zhenskogo terrorizma i problema ego interpretatsii v obshchestve, "Kazanskiy pedagogicheskiy zhurnal" 2016, no. 3, pp. 172-176.

Dvadcat'let religioznoy svobody v Rossii, A. Malashenko, S. Filatov (eds.), Moskva 2009.

Fedorov V., Rossiyskaya identichnost' $i$ vyzovy vremeni. Tezisy $k$ vystupleniyu $v$ Potsdame 5 iyunya 2013 g., https://wciom.ru/fileadmin/file/reports_conferences/2013/2013-06-05-rossiya-ES.pdf [access: 12.02.2018].

Gavrilov Y., Shevchenko A., Russkie musul'mane w pole rossiyskoy identichnosti, [in:] M. Gorshkov (ed.), Rossiya reformiruyushchayasya, Wyp. 7, Institut sociologii RAN, Moskva 2008, pp. 289-303.

Golov A., Obrashchenye $k$ religii i ego znachenye v segodnashney zhyzni rossiyan, "Monitoring obshchestvennogo mnenya" 1998, no. 1 (33), pp. 38-41.

Golubchikov Y.N., Mnatsakanyan R.A., Islamizatsiya Rossii. Trevozhnye stsenarii budushchego, Moskva 2005.

Hałas E., Konwersja - perspektywa socjologiczna, Lublin 1992.

Ignatev A., Pochemu russkie prinimayut islam, http://www.schwarz-front.ru/islam3 00509.htm [access: 20.10 .2014$]$.

Istorii tekh, kto prinyal Islam. Mashha Allakh!, http://al-ihlas.narod.ru/story.html [access: 10.10.2017].

Ivanov V., Radikal'nyy islam sredi russkikh Powolzhya i ego posledstviya, http://www.riss.ru/ analitika/2573-rasprostranenie-radikalnykh-techenij-islama-v-srede-russkogo-naseleniya-povolzhyai-ego-posledstviya\#.VANdK3RmMsc [access: 18.09.2017].

Kazhduyu pyatnitsu v Peterburge kak minimum troe russkikh prinimayut islam, http://www.gazeta. spb.ru/59023-0/ [access: 10.09.2017]. 
Kobishchanov Y., Musul'mane Rossii, korennye rossiyskiye musul'mane i russkiye musul'mane, http://www.tatar-history.narod.ru/musulmane-rossii.htm [access: 10.09.2017].

Kończak I., Motywacje Rosjanek poszukujących muzulmańskiego męża. Próba rekonstrukcji postaw, "Historia i Polityka" 2017, no. 19 (26), pp. 79-95.

Libiszowska-Żółtkowska M., Konwertyci nowych ruchów religijnych, Lublin 2003.

Łabenda M., Muzułmanie w Rosji i europejskiej części byłego ZSRR, [in:] A. Parzymies (ed.), Muzulmanie w Europie, Warszawa 2005, p. 252.

Malashenko A., Naselenie prodolzhat vovlekat' v islam, http://www.carnegie.ru/publications/ ?fa=45245 [access: 23.09.2017].

Naselenie Rossii. Statistika, fakty, kommentarii, prognozy, http://www.rf-agency.ru/acn/stat_ru.htm [access: 10.09.2017].

Pochemu nekotorye russke stanovyatsya musul'manami, http:/www.newsru.com/arch/russia/ 15sep2004/islamm.html [access: 10.09.2017].

Pochemu zhenshhiny prinimayut islam, http://islam-today.ru/zhenshhina_v_islame/pochemu_ zhenshhiny_prinimayut_islam/[access: 12.02.2018].

Russkikh musul'manok stanovitsya vse bolshe..., http://islam-info.ru/zhenskii-razdel/1169-russkixmusulmanok-stanovitsya-vse-bolshe.html [access: 10.10.2017].

Sabirova G.A., Formirovanye religioznoy identichnosti v megapolise (na primere zhenshchin-tatarok, obuchaushchikhsya na religioznykh kursakh v Moskve), Moskva 2006.

Sergeyev I., Russkie musul'manki. Pochemu moskovskiye devushki prinimayut islam?, http://www. centrasia.ru/newsA.php?st=1071330060 [access: 20.10.2014].

Sirazhudinova S., Neofity $v$ strukture radikalnogo islama, "Informatsyonnye voyny" 2015, no. 4 (36), pp. 94-99.

Skoro v Peterburge poyavitsya vtoraya miechet', http://www.fontanka.ru/2007/05/03/083/ [access: 23.09.2017].

Starbuck E.D., The Psychology of Religion: An Empirical Study of the Growth of Religious Consciousness, New York 1911, https://archive.org/details/psychologyofreli00star [access: 12.02.2018].

Stepanova E.A., Religioznaya situatsiya $v$ Rossii $i$ osnovy mezhkonfessional'nykh vzaimootnosheniy, "Nauchnyy ezhegodnik Instituta Filosofii i Prava ural'skogo otdeleniya Rossiyskoy Akademii Nauk" 2003, no. 4, pp. 354-368.

Verkhovskiy A., Publichnye otnosheniya pravoslavnykh $i$ musul'manskikh organizacij na federal'nom urovne, [in:] A. Malashenko (ed.), Islam v Rossii. Vzglyad iz regionov, Moskva 2007, pp. 123-152. 
